Article

\title{
The Uneven Influence of Climate Trends and Agricultural Policies on Maize Production in the Yucatan Peninsula, Mexico
}

\author{
Sofia Mardero ${ }^{1}$, Birgit Schmook ${ }^{1, * \mathbb{C}}$, Jorge Omar López-Martínez ${ }^{2}$, Lizette Cicero ${ }^{3}$ (i), \\ Claudia Radel ${ }^{4}$ and Zachary Christman ${ }^{5}$ \\ 1 Department of Biodiversity Conservation, El Colegio de la Frontera Sur ECOSUR, Chetumal 77014, Mexico; \\ zoophia.mardero@gmail.com \\ 2 CONACYT_El Colegio de la Frontera Sur ECOSUR, Chetumal 77014, Mexico; lmjorgeomar@gmail.com \\ 3 Instituto Nacional de Investigaciones Forestales, Agrícolas y Pecuarias INIFAP, Mérida 97130, Mexico; \\ cicero.lizette@inifap.gob.mx \\ 4 Department of Environment and Society, Quinney College of Natural Resources, Utah State University, \\ Logan, UT 84322, USA; claudia.radel@usu.edu \\ 5 Department of Geography, Planning, and Sustainability, School of Earth and Environment, \\ Rowan University, Glassboro, NJ 08028, USA; christmanz@rowan.edu \\ * Correspondence: bschmook@ecosur.mx; Tel.: +52-983-8335-0440 (ext. 4407)
}

Received: 4 May 2018; Accepted: 23 June 2018; Published: 26 June 2018

\begin{abstract}
Maize is an important staple crop in Mexico, and the recent intensification of climate variability, in combination with non-climatic forces, has hindered increases in production, especially for smallholder farmers. This article demonstrates the influence of these drivers on maize production trends in the three states of the Yucatan Peninsula using a mixed methods approach of climatic analysis and semi-structured interviews. Climate trend analysis and generalized additive models (GAMs) demonstrate relationships between production and climatic variability, using 1980-2010 precipitation and temperature data. Data from forty interviews with government officials and representatives of farmers' associations (gathered in 2015 and 2016) highlight the influence of agricultural policy on maize production in the region. The climate trend analysis yielded mixed results, with a statistically significant negative rainfall trend for Quintana Roo and variability in maximum temperature changes across the region, with an increase in Yucatan State and Quintana Roo and a decrease in Campeche. Climate and production GAMs indicate a strong significant relationship between production and climate fluctuations for Campeche (79\%) and Quintana Roo (72\%) and a weaker significant relationship for the Yucatan State (31\%). Informants identified precipitation variability and ineffective public policies for smallholder agricultural development as primary obstacles for maize production, including inadequate design of agricultural programs, inconsistent agricultural support, and ineffective farmers' organizations. Quantifying the influence of climate change on maize production, and the amplifying influence of national and regional agricultural policy for smallholder farmers, will inform more appropriate policy design and implementation.
\end{abstract}

Keywords: climate variability; smallholder agriculture; subsidies; precipitation; mixed methods; double exposure

\section{Introduction}

The agricultural sector is inherently sensitive to weather conditions and vulnerable to the impacts of globalization [1,2]. Recent discussions regarding the impacts of climate change on agriculture acknowledge that a changing climate not only implies long-term changes in average conditions, but 
also changes in the yearly seasonal variations, including the frequency and magnitude of extreme weather events [3,4]. Non-climate drivers, such as public policy and social, economic, and technological factors, also impact production [5]. Smallholder farmers, hereafter "smallholders," (for a definition of smallholders see Reference [6]) in developing countries are exposed to high levels of environmental, political, and economic stress, Reference [7] affecting their production [8-10]. In Mexico's Yucatan Peninsula, the agricultural sector faces numerous challenges. Increased precipitation variability and frequency of drought events [11], increasing periods of extreme temperatures [12,13], and land degradation [14] together constrain smallholders' efforts to improve crop productivity and food security [15]. Inadequate policy design and implementation further exacerbate these challenges [16].

Several studies have estimated the likely impacts of future climate changes on crop production [17-21], but few studies have considered the joint impacts of climate and non-climate drivers such as policy (e.g., "double exposure" [22]). This article addresses maize production trends in Mexico's Yucatan Peninsula and their temporal relationship with climatic variability, incorporating non-climate drivers, such as agricultural policies. Researchers compared climate variability with maize production yields, trends, and characteristics in the three states of the Yucatan Peninsula over the last 30 years. These results are contextualized by the implications of national and regional agricultural policy and current agricultural programs, via both official reports and semi-structured interviews with representatives from farmers' associations and government agencies.

Results of this study demonstrate how the combined effects of climate variability and agricultural policy have constrained maize production, further exacerbating challenges faced by smallholders. This study provides a basis for new policy interventions that could support more appropriate agricultural programs in the context of changing climatic conditions.

\subsection{Maize: National Context}

Maize is the predominant crop of Mexico, valued as a commodity and for its cultural, political, and social symbolism throughout history [23]. Maize comprises 33\% (7.5 million ha) of the cultivated area throughout the country and contributes $18 \%$ of the agricultural sector's production value (more than 4 billion USD in 2013) [24]. As a subsistence crop, maize ensures the food security of millions of families across the country. Subsistence and semi-subsistence maize cultivation is found in half of all Mexican municipalities [25], and nearly 2.8 million farmers cultivate maize, mostly as smallholders on less than 5 ha $[26,27]$. Cultivation of maize in Mexico is primarily rain-fed ( $80 \%$ by area), although irrigated production has increased substantially from 1980 to 2015, especially in northern Mexico [28].

\subsection{Climate Change Context}

Climate change models for Mexico [29,30] indicate that the country is likely to experience higher temperatures and higher evaporation rates, with a doubling of Carbon dioxide $\left(\mathrm{CO}_{2}\right)$ emissions and greater oscillation in precipitation patterns. Likewise, Méndez-González and colleagues [31] have shown that rainfall regimes in several parts of Mexico have been substantially modified, demonstrating increased rainfall in arid and semi-arid regions and decreased rainfall in dry and wet regions. Further, frequent droughts and hurricanes have threatened Mexico, especially in the Yucatan Peninsula [11,32,33]. Overall, climate models are pessimistic for producers of maize and other grains [34-36].

\subsection{Mexican Agricultural Policy, 1980-Present}

Over the last three decades, Mexico's countryside has faced an economic, environmental, and social crisis as agricultural policies have explicitly prioritized industrial agriculture, relegating smallholders to social welfare programs and to a marginal role in the national and global economy [37,38]. Economic liberalization of the agricultural sector began in the late 1980s and accelerated during the 1990s [39,40], with the negotiation of international trade agreements like the General Agreement of Tariffs and Trade (GATT) in 1986 and the North American Free Trade 
Agreement (NAFTA) in 1994. One of the many consequences of GATT and NAFTA for smallholders was the gradual dismantling of CONASUPO (The Mexican National Company of Popular Subsistence), created in 1962 to ensure the supply of affordable staples and to guarantee prices for producers, and closed in 1998 [41]. The federal government also eliminated guaranteed prices for most crops, restructured input subsidies, reduced subsidized credit for smallholders, and drastically decreased financing of agricultural research and extension [38,42,43].

While most direct subsidies and price supports were eliminated, a new generation of agricultural programs started in the 1990s, redefining the public sector's role in agriculture and rural development. The most important of these newly implemented programs was the Program of Direct Support for the Countryside (Programa de Apoyos Directos al Campo, or PROCAMPO), a cash transfer program, and the Alliance for the Countryside (Alianza para el Campo), a matching grant program for investments in agriculture $[44,45]$. Although the Mexican government has invested considerably in agricultural subsidies (including at least 20 billion USD in direct payments to farmers since 1994), a 2009 World Bank review of Mexican agricultural spending concluded that more than half the funds were directed to the richest $10 \%$ of producers. For PROCAMPO, 44\% of the total spending for the period 1994-2008 was concentrated among the wealthiest $5 \%$ of farmers, whose economic success may not depend on these subsidies [46]. By contrast, the poorest $80 \%$ of beneficiaries received just under $27 \%$ of spending. Funds dispersed from 1995 to 2003 were substantially less than funds dispersed from 1989 to 1994, indicating that trade liberalization after 1994 was paired with decreased agricultural subsidies [47].

\section{Materials and Methods}

\subsection{Study Area}

The study was conducted in the Yucatan Peninsula of southeastern Mexico (Figure 1), an area of about $145,000 \mathrm{~km}^{2}$, including the states of Campeche, Yucatan State and Quintana Roo. The Yucatan Peninsula is a physiographic region consisting of a karstic platform with marked carbonate rock layers [48]. Karstic landscapes result in considerable spatial heterogeneity in soil groups. Leptosols comprise $75 \%$ of the landscape [49-51], and their variability, stoniness, and shallowness complicate mechanized agriculture [50-53]. Other dominant soils are Vertisols, rich in organic matter, but susceptible to erosion and poor drainage [54]. Phaeozem soils are also found in the three states (17\% of Campeche, $8 \%$ of Yucatan State, and 10\% of Quintana Roo). Soils in this group are more fertile, deeper, and less stony than Leptosols, facilitating mechanized agriculture. The estimated potential for mechanized agriculture (as a proportion of all the land suitable for agriculture in each state) is as follows: Campeche, 61\%; Quintana Roo, 43\%; and Yucatan State, 20\% [55].

Drainage in this karst landscape is primarily underground, with a network of sinkholes or cenotes [56], with little surface water. The annual rainfall varies from less than $125 \mathrm{~mm}_{\text {year }}{ }^{-1}$ at the western end of the Peninsula, to more than $1500 \mathrm{~mm}_{\text {year }}{ }^{-1}$ on the eastern coast, with most regions experiencing 800-1200 mm year ${ }^{-1}$ [55]. Climate in the Peninsula [57] is tropical wet and dry (Aw) across most of the area, and semi-arid (BS1) in a small portion of the Northwest of Yucatan State.

Maize production varies across the three states of the Yucatan Peninsula, in both area and yields (Table 1). Campeche has the highest maize production in the Yucatan Peninsula, for both yield and area cultivated. Campeche also experienced the largest percentage increases in area cultivated, average yield, and total annual production from 1980 to 2015. 


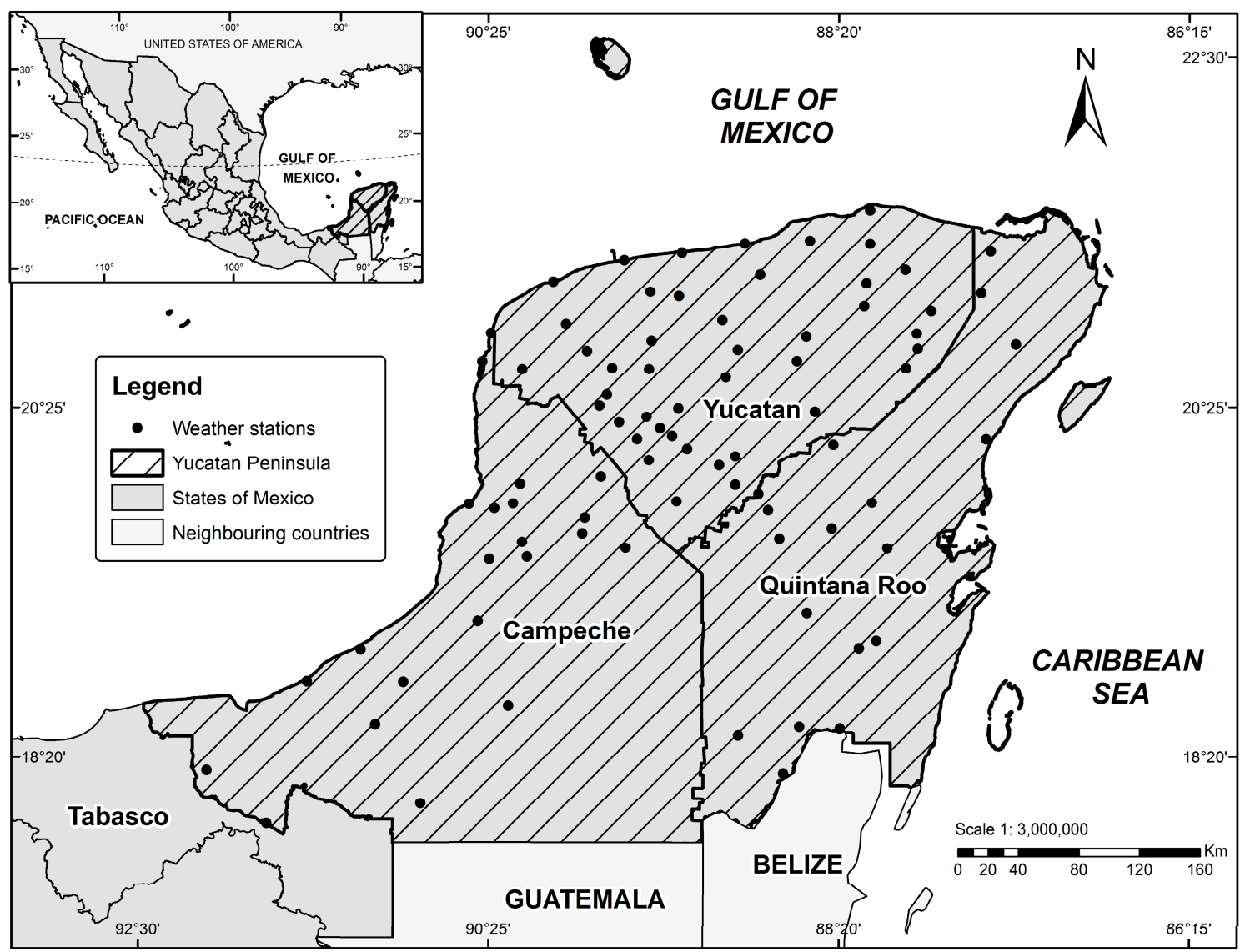

Figure 1. Study area, including the weather stations used for the analysis.

Table 1. Extent of maize, per hectare yield, and total production per state for 2015, both rain-fed and irrigated. Source of data: Agricultural and Fisheries Information Service (SIAP).

\begin{tabular}{|c|c|c|c|c|c|c|c|c|c|c|c|}
\hline \multirow[t]{2}{*}{ State } & \multirow{2}{*}{$\begin{array}{l}\% \text { Total } \\
\text { Land } \\
\text { Cultivated }\end{array}$} & \multicolumn{3}{|c|}{ Yield (ton/ha) } & \multirow[t]{2}{*}{$\begin{array}{l}\begin{array}{c}\text { Total } \\
\text { Production } \\
\text { (ton/year) }\end{array}\end{array}$} & \multicolumn{3}{|c|}{ Area Planted (ha) } & \multicolumn{3}{|c|}{$\begin{array}{c}\text { \% Increase } \\
(1980-2015)\end{array}$} \\
\hline & & Rain-Fed & Irrig. & Average & & Rain-Fed & Irrig. & Total & Area & Prod. & Yield \\
\hline Campeche & 71 & 2.3 & 5.2 & 3.8 & 407,201 & 183,173 & 2568 & 185,742 & 241 & 790 & 90 \\
\hline Q. Roo & 83 & 0.6 & 2.4 & 1.5 & 38,700 & 78,364 & 1985 & 80,349 & 55 & 44 & 46 \\
\hline Yucatan State & 93 & 0.6 & 4.5 & 2.5 & 75,324 & 107,868 & 8600 & 116,469 & -21 & -17 & 44 \\
\hline
\end{tabular}

Mexico's Agricultural and Fisheries Information Service (SIAP) collects maize production data, which allows assessment of changes in maize yield and area under cultivation [28]. Rain-fed maize area showed no overall increase or decrease for the studied period, 1980-2015, for Quintana Roo and the Yucatan State, but the Yucatan State exhibited a decrease in cultivated area for the last ten years of the period, 2005-2015, while the cultivated areas of Campeche steadily increased, especially after 1993 (Figure 2). The total annual production and average maize yields were similar for each state, with an increase in irrigated cultivation, resulting in higher average yields and total production since 2008. During this period, Campeche rose in maize production ranking among Mexican states, from the 23rd to the 10th place. 


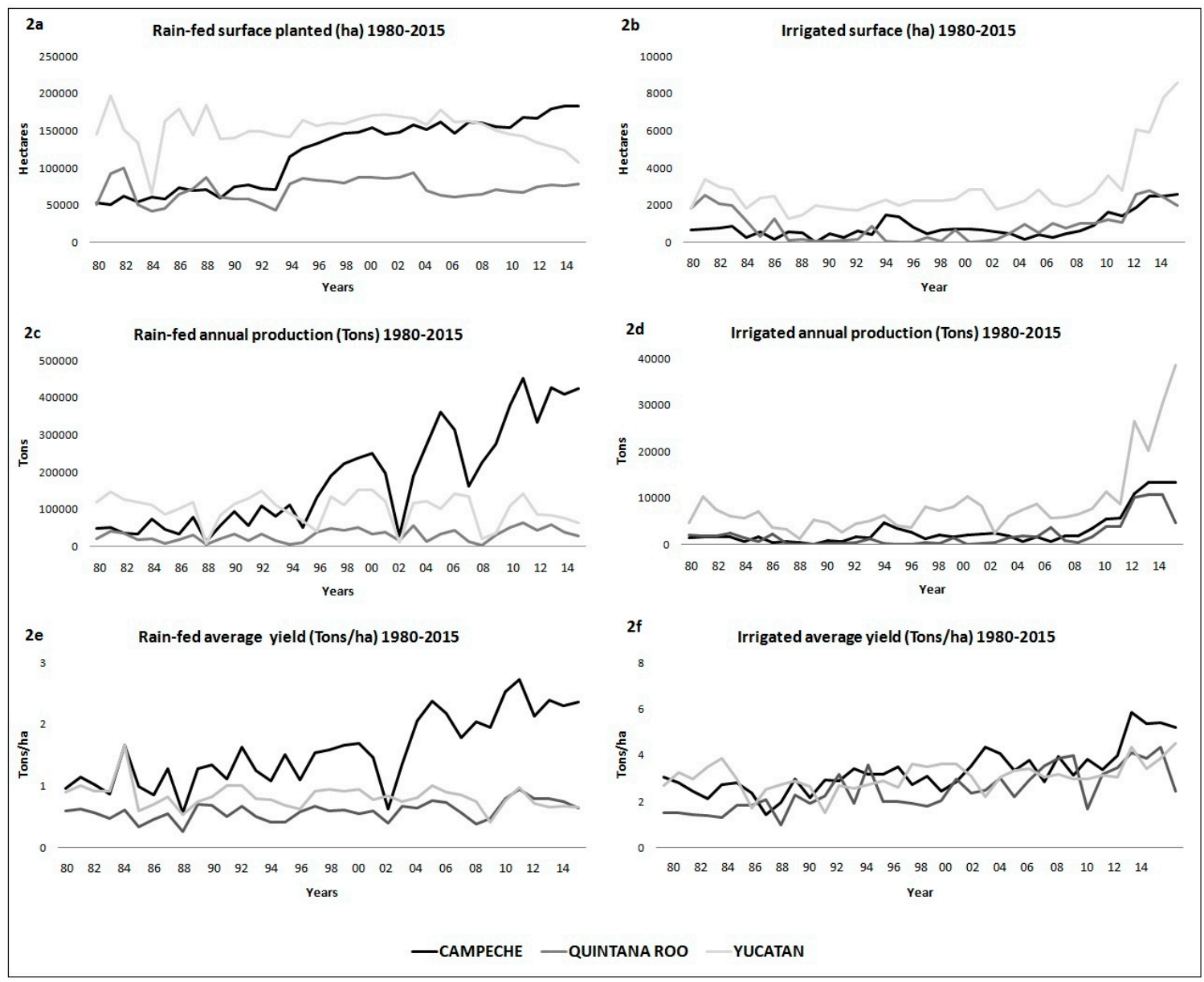

Figure 2. Surface area planted in maize, annual maize production, and average maize yield in Campeche, Quintana Roo, and Yucatan State, 1980-2015, by type of production (rain-fed or irrigated).

In Campeche, in addition to soils better suited for mechanized agriculture [58], large Mennonite colonies in the municipalities of Hopelchen and Hecelchakán contributed to the state's greater maize production. In addition, Campeche's public policy expenditures prioritized agricultural production, while Quintana Roo emphasized tourism and the Yucatan State prioritized both livestock production and tourism.

\subsection{Mixed Methods Approach}

A mixed methods approach [59] was used for this research, offering an opportunity to draw from the strengths of both quantitative and qualitative research approaches [60]. Although mixed methods research is not entirely new, it is a new trend in interdisciplinary research that has arisen in response to the current need to address topics requiring study from different but complementary perspectives, using both general research approaches, quantitative and qualitative [59]. Quantitative data for climatic variables and maize production trends and GAM models were collected from official governmental sources (https:/ / www.gob.mx/sagarpa, subsidiosalcampo.org.mx). Qualitative data were gathered through 40 in-depth, semi-structured interviews with key informants, with interviews ranging from 1 to $3 \mathrm{~h}$. Further evidence of agricultural and climatic trends was collected from a review of previous scientific and agricultural program reports. When appropriate, direct quotations from interviewees are used with attribution and locations, following [61].

Mixed methods research enables the integration and contextualization of conclusions that are drawn from each strand of the research [62,63]. In this study, analyses of quantitative and qualitative 
data were undertaken independently, and are integrated in the discussion. Approaches taken for data analysis are detailed in the following two sections.

\subsection{Quantitative Data and Analysis: Maize Production and Climatic Variability}

Official yearly maize production data from SIAP (the administrative body in charge of generating statistics and geographic information on agrifood matters, and the only data source available for annual crop production in Mexico) were related to temperature and precipitation data from the monthly records of the weather station network of the National Meteorological Service (SMN). The variables used were minimum temperature (Tmin), maximum temperature (Tmax), and accumulated precipitation (Precip), summarized into monthly averages. The selected study period for this analysis was 1981 to 2010, because only for this period are complete data sets available for all variables. For this reason, the period for this climate-production analysis is five years short of the study's longer period of assessment from 1980 to 2015.

Data from 80 weather stations (Figure 1) in the region were gathered. Missing data from all stations were interpolated using Generalized Additive Models (GAMs), nonlinear models comprised of the sum of smoothed functions (consisting of a series of local regression-type models), rather than linear functions $[64,65]$. These models are widely used in analysis of time series, enabling non-parametric adjustments and nonlinear effects of seasonality and trends [66].

To address the temporal variation of climate data, the time series was decomposed into three components: trend, seasonality, and randomness, based on an analysis of moving averages, using the software R 3.4 [67]. Linear models were conducted to determine the presence of trends for each climate variable over the time-period. To determine the relationship between climate variability and maize production, GAMs were generated using the variances of climate data (Tmax, Tmin, and Precip) as independent variables, by year. Annual maize production (tons) served as the dependent variable. Four models were built: one for each of the three states and one for the entire Peninsula. Because the dependent variable is discrete, the GAMs used a Poisson distribution. All models were generated with the "gam" function from the "mgcv" package of R 3.4 [68].

Precipitation anomalies were calculated to address years with a deficit or surplus of precipitation. Anomalies are calculated as the percentage difference observed in a year, month, or specified time, " $i$ " $(\mathrm{P} i)$, compared to the average of a specified period $(\mathrm{P})$ :

$$
\text { Anomaly }=(\mathrm{P} i-\mathrm{P}) /(\mathrm{P} \times 100) .
$$

\subsection{Qualitative Data and Analysis: Perceived Causes and Influences}

Forty in-depth, semi-structured interviews were conducted between October 2015 and February 2016, following the practices of a grounded theory framework, based on the collection and systematic analysis of empirical data, without specific theory or initial hypothesis [69]. The type of sampling that is done based on the Grounded Theory is called Theoretical Sampling. In it, the size of the sample is not known a piori. The structuring of this is done gradually throughout the research process and is not done according to criteria of representativeness but according to the relevance of the cases $[69,70]$. The sampling ends then, when reaching the Theoretical Saturation, which means that no new data are found through which more questions can be developed. The incorporation of new material or new data ends, according to this concept, when nothing new emerges [71].

Interviews were conducted with members of farmers' grain-production associations and government officials. Federal agencies included SAGARPA (Secretary of Agriculture, Livestock Production, Rural Development, Fishery and Food, six interviews), CONAGUA (National Water Commission, three interviews), and INIFAP (National Institute of Forestry, Agriculture and Livestock Research, three interviews). State agency interviews included six interviews with staff from the Ministry of Rural Development, Campeche (SDR); the Ministry of Agricultural and Rural Development, Quintana Roo (SEDARU); and the Ministry of Rural Development, Yucatan State (SEDER). Further 
interviews included the directors of the Maize Commodity System (Sistema Producto Maíz) of each state and representatives from various farmers' associations, ranging from subsistence to commercial producers, with memberships of 20 to 10,000. Interviewees included not only farmers, but also federal government officials related to the agricultural sector, in order to achieve a more complete and broad set of perspectives on the situation of maize production.

The survey instrument consisted of a list of topics related to climate change and variability, issues faced by maize producers, agricultural programs, and subsidies, and how these elements were perceived to interact and influence maize production. Most of the interviews were audio recorded (with consent) and transcribed. Using the Atlas.ti software, transcripts were analyzed for dominant themes and language use [72]. Transcript analysis was conducted in three stages: (a) organization of information (field notes, written interviews), the transcription of recorded interviews, collection, and organization of information to be analyzed; (b) analysis to decompose the information in analytical units, to identify the drivers for maize production, and to assign codes to these drivers. These first steps of analysis helped us to build first level categories and subcategories and then identify the different parts of the testimonies, which fall into each category. For example, the category for the influence of climate change on production was refined into sub-categories for droughts, rainfall variability, and hurricanes. This process enabled the identification of similarities or differences among testimonies and the creation of networks between them. With the information of each interview falling in the created categories, was it possible to address, which are the main drivers of maize production; (c) analytic interpretation, including description of the findings and their theoretical interpretation.

This study did not quantify the relationship between the non-climate drivers and maize production (as with the climate drivers and production), and a structured list of questions was not used, unlike as has been used by Adger [73], Eakin [7], and O'Brien \& Leichenko [22] to analyze the influence of multi-stressors (climate change and globalization) on smallholders in Mexico and other parts of the world.

\section{Results}

\subsection{Climate Trends, Precipitation Anomalies, and Climate-Production Analysis}

Historical precipitation data from the 80 weather stations show significant negative trends for total precipitation from 1981 to 2010 in Quintana Roo $\left(R^{2}=-0.1393, p<0.0001\right)$; however, total precipitation in the Yucatan State and Campeche did not exhibit any directional trend $\left(R^{2}=0.04637, p<0.0001 ; R^{2}\right.$ $=0.00176, p=0.428$, respectively). Maximum temperatures in Quintana Roo and the Yucatan State experienced a slight increase $\left(R^{2}=0.03396, p<0.0001 ; R^{2}=0.03119, p=0.0005\right.$; respectively), and in Campeche maximum temperature followed a negative trend $\left(R^{2}=-0.40771, p<0.001\right)$. The minimum temperature exhibited a positive trend in all three states (Figure 3).

Precipitation anomaly results (Figure 4) show that most of the years with the highest negative anomalies coincided for the three states, in 1986, 1994, and 2009, matching occurrences of El Niño events. Anomaly analysis also indicates that Quintana Roo experienced the highest negative anomalies, and from 2000 onwards, Quintana Roo had a precipitation deficit in almost every year (Figure 4). 

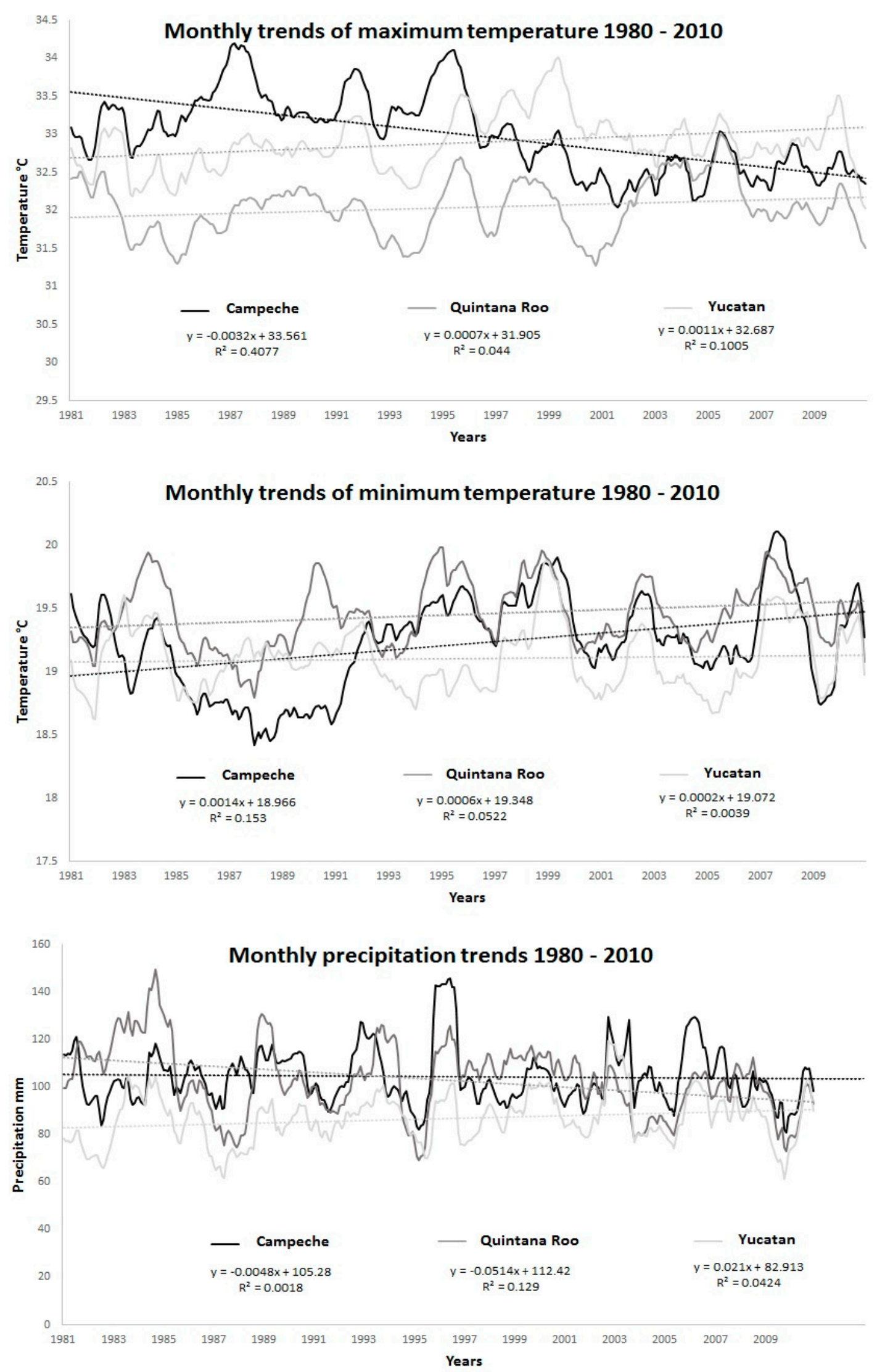

Figure 3. Trends for maximum temperature, minimum temperature, and precipitation for each state, from 1981 to 2010. 


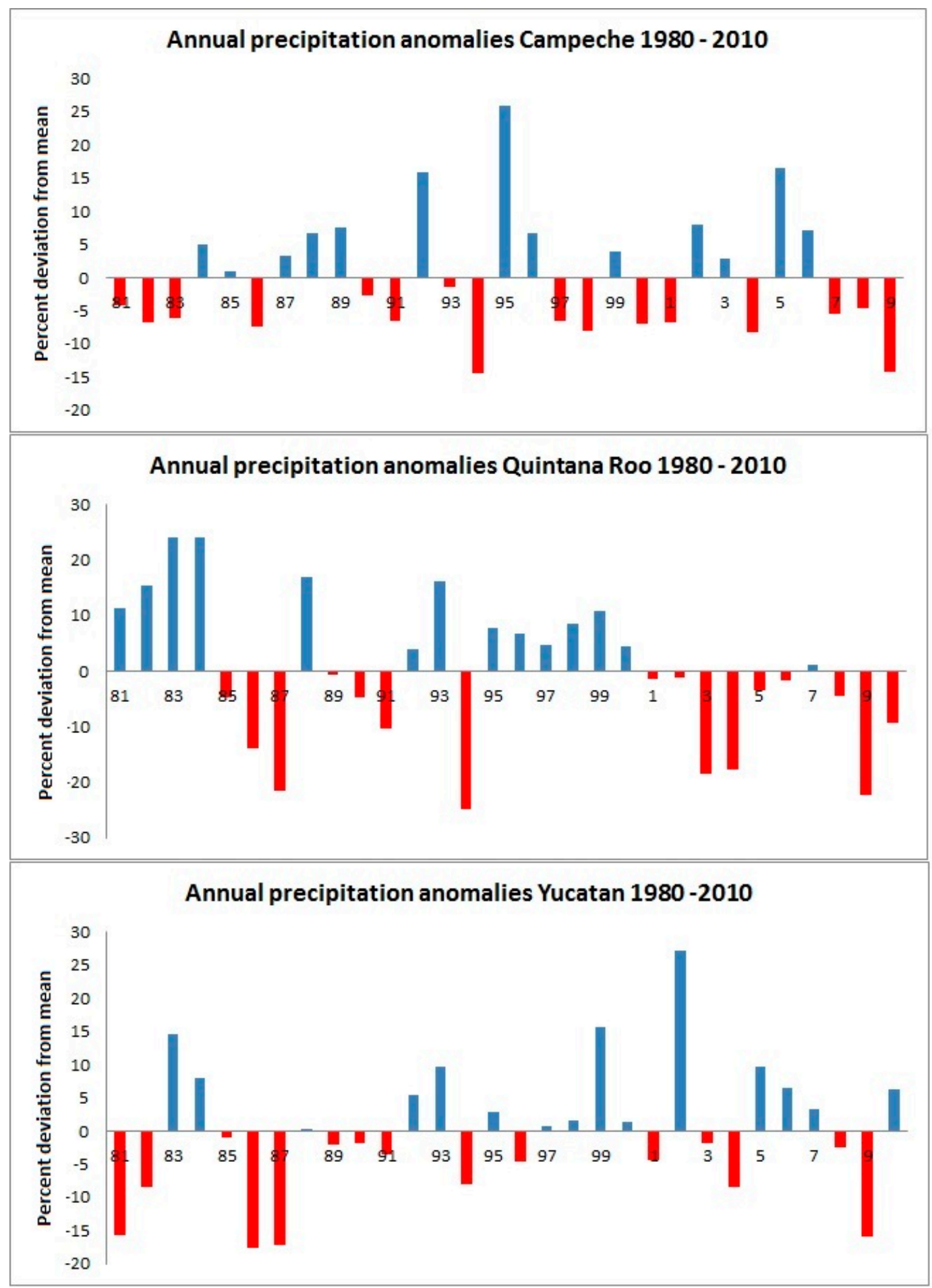

Figure 4. Annual precipitation anomalies for the three states, 1981-2010.

The relationship between climate variability and maize production for the 1981-2010 period was modeled for each of the three states and for the Yucatan Peninsula as a whole. The more robust models are for the states of Campeche and Quintana Roo, with an adjusted $R^{2}$ of 0.79 and 0.72 respectively, indicating that 79\% of the variability of Campeche's maize production and 72\% of Quintana Roo's are explained by concurrent variability in precipitation and temperature. In both the Yucatan State and in the Peninsula as a whole, the relationship between climate variation and production for the 1980-2010 period is somewhat weaker. The climate variables explain only $31 \%$ of the production variation for 
Yucatan State model, and only 28\% for the Peninsula model. The independent variables (Year, Tmax, Tmin and Precip) are each significant in all models.

Precipitation variability follows a very similar pattern in the four models: maize production is greater when there is less variability in precipitation. In the case of maximum and minimum temperatures, the models show no clear pattern. However, in general, the largest maize production occurred in those years in which the variability in maximum temperatures was low.

\subsection{Perceptions of Climate Change and of Its Effects on Production}

All interviewees indicated that climate change is a major challenge facing maize producers. Rainfall variability, which could mean several days without rain, followed by concentrated rainfall in a short time period, causes flooding in farm plots and detrimental water saturation in the soils, risking crop failure. Strong hurricane winds or tropical storms devastate plots, and droughts, which producers perceived as increasingly frequent and intense, directly result in large production losses, and enable the proliferation of pests.

Testimonials do not reflect perception of an overall decrease in precipitation over the last three decades. Respondents instead focused on describing changes in precipitation patterns, as rainfall has become extremely unpredictable and scattered both spatially and temporally:

"The main problem of agriculture itself is the weather. Everything was based on rain-fed [agriculture]:

It used to be a regular and predictable weather but now is totally erratic." Santiago Arjona,

Secretariat of Rural Development, Campeche.

According to interviewees, without predictable rainfall, farmers must modify their agricultural calendar according to each year's or season's characteristics. Consequently, the spring-summer crop cycle may overlap with the winter crop cycle, or water-intensive stages of plant development may coincide with the canicula, or mid-summer drought. Crops can also be more affected by heat waves, by the "strong winds" of October, and by the presence of pests. There is also an increase in labor and production costs: In many cases, producers prepare the land according to the usual sowing calendar, but with delayed rains, they must repeat this labor.

With respect to temperatures, interviewee perceptions align with results of the climate trend analysis, emphasizing that maximum temperatures have increased with time. Interviewees reported a negative effect on maize production due to the direct effect of temperatures on yield:

"... it has been considered that we should measure per hectare productivity, especially of those crops that are rain-fed. High temperature periods have increased and this stresses the crop for a longer time, making the yield go down, and maybe this is not considered as 'agricultural losses,' but these areas will have a lower productivity." Raul Diaz Plaza, INIFAP.

\subsection{Agricultural Programs and the Effects on Maize Production}

Interviews and a review of official materials on agricultural programs inform the study's findings on the role of agricultural policy in production, for rural and indigenous Mayan smallholders in Quintana Roo, Campeche, and the Yucatan State. The restructuring of the agricultural sector in the Yucatan Peninsula, as well as the intensification of tourism since the 1980s, has created new livelihoods and new socioeconomic dynamics [74]. Agricultural policies have primarily benefitted the largest producers by basing subsidies on the area under cultivation (as with PROCAMPO), with limited support for inputs (like under PIMAF, the Incentive Program for Maize and Bean Producers) and some support from social welfare programs (like Prospera, Mexico's primary anti-poverty cash transfer program). Pressure to modernize agricultural production and to cope with a changing climate has resulted in soil degradation and loss of fertility, coercing maize producers to employ a number of strategies to access monetary supports and agricultural inputs in order to maintain or increase yields.

The most common programs accessed by interviewed farmers were PROCAMPO and PIMAF, which provide small monetary supports, seeds and other inputs, and some technical assistance. 
Producers trying to market their crops can also get support (assistance for commercializing, advice on national and international markets and on promoting their products, and so on) from ASERCA (Agency for Services of the Marketing and Development of Agricultural Markets). Producers often receive insurance for their crops for cases of catastrophic loss. For smallholders, the insurance is usually provided (without cost) by government agencies (about 1500 pesos to each producer per hectare affected by climatic events), while commercial farmers contract commercial insurance companies. Producers with the financial means often install irrigation systems, which may be partially subsidized with governmental funds. See Appendix A Table A1 for more details on support programs used by maize producers in the Peninsula.

To apply new production techniques, agricultural producers use various combinations of monetary support and agricultural inputs offered by government programs, payments for environmental services, insurance against climatic disasters, and credit (usually through Financiera Rural). However, the application procedures, eligibility, and delivery of these support programs can be difficult to navigate, especially for smallholders. Farmers may be ignorant of the rules of operation, they may lack the necessary guarantors to obtain financing, or they may face difficulties in meeting program requirements or payments to service providers. According to representatives of maize producer organizations, service providers, and the Director of the Maize Commodity System, the primarily problem producers face is the substantial delay in the delivery of monetary support and supplies, even after successfully demonstrating eligibility.

Farmers also noted gaps in the continuity and distribution of agricultural programs, with few and scattered allocations to many producers rather than focused disbursements in strategic areas. Farmers attributed these challenges to the federal structure of these programs, which they claimed was misaligned with the environmental, economic, and social characteristics of the Peninsula. Interviewees perceived that most programs are not oriented towards subsistence producers at all, but focus on commercial agriculture, with no agricultural development plan that is working for the needs of subsistence smallholders.

\section{Discussion}

\subsection{Production Trends, Climate Trends, and the Climate-Production Relationship}

While rain-fed production in Mexico and the Peninsula remains stagnant $[39,75,76]$, irrigated production has increased substantially, especially since 2010. Previous research has offered various explanations for this stagnation in rain-fed maize production, including neoliberalization at multiple economic scales [77,78]; agricultural policy focused on increasing technical inputs for producers with commercial potential [38]; declining and greater variability in precipitation [29,79]; and the expansion of a "modern" sector (especially in northern Mexico) that has rapidly adopted new production technologies and increased the area under irrigation [39].

Each state of the Peninsula has its own characteristics that influence maize production (Table A2) in the appendix summarizes the drivers for maize production trends in the Yucatan Peninsula). Among the three states, maize production has the greatest correlation with climate variability in Campeche. This is notable, because Campeche has had a relatively stable climate over the last 30 years and is the state with the highest and still-increasing maize production. Campeche also has more suitable soils for agriculture and the highest budget devoted to the agricultural sector, the highest funding from PROCAMPO, the greatest percentage of mechanized surface, and the greatest use of improved seeds.

Quintana Roo also demonstrates a strong relationship between climate variability and production, as well as the greatest climate variability, resulting in lower total maize production and yields. Quintana Roo also has the lowest budget for SAGARPA, the lowest expenditure of PROCAMPO funds, the lowest number of beneficiaries of the program $(22,000)$, and, compared to Campeche, a lower percentage of the federal expenditure budget devoted to agriculture and less surface planted with improved seeds. Soils are not as good as in Campeche, but not as poor as in the Yucatan State. The Yucatan 
State presents the weakest relationship between climate variability and production, suggesting that a primary limitation for agriculture in Yucatan State may not be climate, but rather soils. In addition, in Yucatan State, economic policy focuses on livestock and tourism, devoting the lowest percentage of the state budget to agriculture, among all the other sectors.

Precipitation and temperature in the Yucatan Peninsula do not show very marked trends of change throughout the study period; however, some changes in precipitation and temperature in Quintana Roo are evident, which, although small, are statistically significant. This difference among the states could be explained by Quintana Roo's exposure to the trade winds, making it more susceptible to variations in the intensity and amount of humidity and heat they carry [11]. The inability to identify marked trends in these variables does not imply there have been no changes in climate. According to the Intergovernmental Panel on Climate Change (IPCC) report [80], the effects of climate change on precipitation, for example, rather than decreasing or increasing annual or seasonal averages over time, occur mainly in the intensity and distribution of rains; however, these data are not sufficiently available for analysis.

The amount and distribution of precipitation is widely recognized as among the most important determinants of yields in agriculture, followed closely by temperature $[81,82]$. INIFAP researchers interviewed cite as important to production in the Yucatan both temperature increases over time (especially maximums) and increases in the frequency and duration of high temperatures. In addition, cyclic events such as El Niño are known to have a strong influence on maize production in the study area $[39,77]$. In this study's analysis, climatic factors bore a strong influence on production in each of the states; although, as other studies of agricultural and rural vulnerability have shown $[7,10,83]$, among others), climate conditions and climate risk are not the only, and sometimes not even the most important, determinants of production.

\subsection{Agricultural Policy}

Support for agricultural production is highly concentrated in a few Mexican states, primarily in the north, and targeted towards few producers, which deepens social and economic inequalities. According SAGARPA, in Quintana Roo producers with less than 5 ha represented $90 \%$ of the PROCAMPO beneficiaries in 2016, receiving $84 \%$ of the program's funds. In the Yucatan State, the comparable group represented $96 \%$ of beneficiaries and got $90 \%$ of funds. In Campeche, by contrast, producers with less than 5 ha represented $80 \%$ of beneficiaries but received only $55 \%$ of transfers. In short, Campeche allocated more support to large commercial producers, potentially increasing overall production. This may also indicate that, in Campeche, more farmers have achieved the transition from small, semi subsistence producer to commercial producer. In the Yucatan Peninsula as a whole, $87 \%$ of the agricultural producers who benefited from PROAGRO cultivate 5 hectares or less. According to government officials, agricultural policies in the Peninsula, as in Mexico overall, intend to foster and stimulate capital- and input-intensive agriculture. Greater production, on less area, with pre-designed technology packages and irrigation systems, serves to accentuate the polarization between famers who are able to make the transition and those who cannot. In a review of more than 300 studies on the Green Revolution from 1970-1989, Freebairn [84] demonstrated that about $80 \%$ of studies on the distributional effects of the new technologies found that inequality increased, both inter-farm and inter-region. The benefits of subsidies vary from producer to producer. Agricultural policymakers in Mexico are quite explicit about giving large growers priority [37,38], and policymakers decide which producers have the necessary productive potential to receive irrigation facilities, subsidies for water use [38], and other technology supplements. Smallholders are relegated to poverty relief and non-productive programs such as PROSPERA, which provides cash transfers conditional on health and education behaviors. In more than half of the country's municipalities (1570/2240), especially in the southern states, the primary social spending comes from the Ministry of Social Development (SEDESOL); in only 358 municipalities is SAGARPA the predominant program. Hence, in the rural 
smallholder sector, the aim is to combat poverty through welfare programs, rather than through increasing income and employment through a stimulated agricultural sector [85].

\subsection{Interaction between Climate Variability and Agricultural Programs}

The "new" climate characteristics further exacerbate the polarization in Mexican agriculture, according to respondents. The changing climate has led to a search for new ways to produce, accompanied by a reliance on different types of inputs and mechanization, which most producers can only afford with government support. Yet this support largely is not oriented to smallholders. Climate variability coupled with delays in the delivery of monetary support and inputs increase vulnerability to production losses by interrupting the timing of agricultural activities. While these factors may restrict traditional rain-fed agriculture, they may also affect the capacity of smallholders to transition into commercial agriculture. For small producers seeking financial support, climate uncertainty and the unreliability of agricultural programs are important obstacles. Interviewees expressed fear that, if they were able to invest money or credit, production failure would result in personal financial debt.

As already discussed, climate and soil conditions influence the agricultural policy and budget of each state, with decisions based on identified agricultural potential. Accordingly, the Yucatan State and Quintana Roo have prioritized their tourism sector, which may be more profitable than agriculture, given the limitations of soil and climate. Rather than abandoning the smallholder sector altogether, there has been re-focused investment in social services for rural areas considered less competitive in national maize markets [86,87]. Smallholders themselves have not widely abandoned maize farming; instead, they sustain their practices through different agricultural supports, social assistance programs, labor diversification, and investment of money earned through temporary migration $[16,32,77]$. One recent study in Campeche demonstrates how the anti-poverty program Oportunidades (now PROSPERA) enabled semi-subsistence maize production to persist during part of the time-period in question [88]; while another Campeche study related poverty alleviation programs with a shift away from production for self-consumption and towards the purchase of industrial foods [89]. These studies suggest that the relationship between smallholder production and social support programs is complex. Smallholders lack alternatives and may persist in maize production because of its critical role in rural culture and livelihoods. Despite the difficulties caused by the climate and market, many smallholder households have maintained their maize cultivation for subsistence and cultural reproduction, subsidized by off-farm employment and governmental transfers [16]. Nevertheless, this production remains marginal and without prospects for improving smallholder wellbeing.

\section{Conclusions}

Yields of rain-fed maize in the Yucatan Peninsula remained stagnant for the period 1980-2015, while areas planted diminished. Irrigated production, on the other hand, steadily increased, in an effort to meet Mexico's growing demand for maize and reduce dependency on maize imports. Nevertheless, irrigation systems and other agricultural inputs polarize Mexican farmers by their ability to access and afford these resources. Measurable and statistically significant climactic changes have affected the entire Peninsula, especially in Quintana Roo, and current climate characteristics make traditional maize cultivation economically marginal. This situation has led to new modes of production, with different types of inputs and mechanization, and has made many smallholders dependent on funding programs and supports.

In addition to a changing climate, limited access to new technologies, high dependence on government support, and the shallow, stony soils across much of the Yucatan Peninsula together influence the low overall maize production. With these interacting influences, the small-scale agricultural sector has experienced a crisis dating back to the 1980s. Results of this study demonstrate that an integrated combination of the biophysical conditions shaping production and the economic, policy, and program-implementation conditions shaping access to markets and incentives have 
created this crisis in smallholder agriculture, experienced as low yields for rain-fed maize production. Nevertheless, smallholders have not widely abandoned maize farming and are combining this ancestral activity with a diversification of income-generating activities and government assistance [16].

Other studies in Central Mexico [7] found that agricultural policy changes play a far more prominent role in farmers' livelihood and production strategies than does climatic risk. In contrast, even though we found that agricultural subsidies do play an important role in agricultural production, we also found a strong relationship between maize production trends and climatic trends in two of the three states of the Peninsula. Appendinni and Liverman [32] documented the influence of climate risk and agricultural policy on smallholders for the period since 1994, arguing that agricultural policy might influence the way smallholders respond and adapt to climate change, but that the impact would be differentiated according to region, crop, and type of farmer.

Arce et al. (2018) [90] stated that it is necessary that small-scale producers be included in Mexico's Special Climate Change Program (Programa Especial de Cambio Climático PECC 2014-2018), in order to have a positive impact on these producers' crop production, food security and livelihoods, all of which are already highly affected by climate change. This program is one of the planning instruments of Mexico's General Law on Climate Change, and it contains a diagnosis of the country's situation with respect to climate change. The program has 26 strategies and 199 lines of action, of which 77 correspond to adaptation to climate change, 81 to its mitigation, and 41 to the construction of a state policy on the subject, but the program does not contemplate a single line of action that takes into account the impact of climate change on small-scale rural producers.

Vergara and colleagues [91] have suggested that current agricultural policies, developed over time and without regard to the climate challenge, should be revised to channel public resources in new ways which are consistent with low-carbon, climate-resilient agriculture, as well as to promote investment in public goods such as agricultural research and extension services. By characterizing how observed climatic change and concurrent agricultural policies combine to influence maize production, this research can provide insight to decision makers, for more appropriate policy design and implementation. This study further advances this insight by integrating analysis of the climate-production relationship with the perceptions of the many different actors engaged in support programs, to better understand ways to increase smallholder wellbeing in the face of increasing climate variability.

The analysis of the joint impacts of climate change and agricultural policy, through a mixed method approach, is the main strength of this research, as this kind of study has never been undertaken for the Yucatan Peninsula and is uncommon elsewhere. An analysis of maize production trends, related only to climatic characteristics, would be incomplete and would not provide the full context under which maize producers operate. By the same token, it is not possible to examine the influence of public policy on maize production, without considering the influence of a changing climate. The main weakness of this study is the inability to address the differentiated impacts (of climate change and agricultural policy) on small- versus large-holders because of the unavailability of maize production data that distinguish agricultural holdings by size. Available data allow distinguishing only between rain-fed agriculture and irrigated agriculture. Another study weakness relates to scale. Based on the available agricultural data, the production and climate analyses were conducted for each state, resulting in the loss of detail on important climatic and production variations across states. A final weakness is the study's inability to integrate the influences of climate and policy into unified analyses. The analysis of the influence of policy and its programmatic implementation relies on the perceptions of key actors, both state employees and farmers and their representatives.

Results from this study could be used by policy makers to elaborate agricultural policies targeted to increase maize production in the context of future climate impacts. With more appropriate policies that enhance smallholder resilience and production capacity rather than provide only social assistance, small-scale producers can be supported to develop greater flexibility to adjust to changing environmental stress. 
Author Contributions: Conceptualization, S.M., J.O.L.-M. and B.S.; Methodology, S.M., J.O.L.-M., B.S. and L.C.; Formal Analysis, S.M., J.O.L.-M. and L.C.; Investigation, S.M.; Project Administration, S.M. and B.S.; Writing-original draft, S.M., B.S., J.O.L.-M. and L.C.; Writing—Review and Editing, S.M., B.S., C.R. and Z.C.

Conflicts of Interest: The authors declare no conflicts of interest.

\section{Appendix A}

Table A1. Programs, supports and strategies used by maize producers in Mexico's Yucatan Peninsula.

\begin{tabular}{|c|c|c|}
\hline Program, Support or Strategy & Type of Support & Institution in Charge \\
\hline $\begin{array}{l}\text { Program of Direct Support to the } \\
\text { Countryside (PROCAMPO, } \\
\text { PROAGRO) }\end{array}$ & Monetary support on a per hectare basis & $\begin{array}{l}\text { Ministry of Agriculture, Livestock, } \\
\text { Rural Development, Fisheries and } \\
\text { Food (SAGARPA) }\end{array}$ \\
\hline $\begin{array}{l}\text { Agency for Services of the } \\
\text { Marketing and Development of } \\
\text { Agricultural Markets (ASERCA) }\end{array}$ & $\begin{array}{l}\text { Promotes marketing through incentives to } \\
\text { producers and buyers of agricultural products; } \\
\text { granted on a selective basis by region and crop } \\
\text { type. }\end{array}$ & SAGARPA \\
\hline $\begin{array}{l}\text { Incentive Program for Maize and } \\
\text { Bean Producers (PIMAF) }\end{array}$ & $\begin{array}{l}\text { Provides maize and bean producers with free } \\
\text { improved seeds; agrochemicals and implements } \\
\text { for planting, harvesting and storage; and } \\
\text { technical support }{ }^{1} \text {. }\end{array}$ & $\begin{array}{l}\text { SAGARPA and the Secretaries of } \\
\text { Rural Development of each state }\end{array}$ \\
\hline Technological packages & $\begin{array}{l}\text { Suggests all inputs needed for one hectare } \\
\text { cultivated with maize (in this case), to be able to } \\
\text { achieve target yields, according to state's } \\
\text { environmental characteristics; cost of packages } \\
\text { varies depending on state }{ }^{2} \text {. }\end{array}$ & $\begin{array}{l}\text { Designed by National Institute of } \\
\text { Forestry, Agriculture and } \\
\text { Livestock (INIFAP), implemented } \\
\text { by SAGARPA and the Secretaries } \\
\text { of Rural Development of each } \\
\text { state through different programs. }\end{array}$ \\
\hline Irrigation systems & $\begin{array}{l}\text { Pays } 50 \% \text { of the total costs of the irrigation } \\
\text { system and recovers abandoned } \\
\text { hydro-agricultural drainage }\end{array}$ & $\begin{array}{l}\text { National Water Commission } \\
\text { (CONAGUA) and SAGARPA }\end{array}$ \\
\hline $\begin{array}{l}\text { Agricultural insurance for } \\
\text { catastrophic events }\end{array}$ & $\begin{array}{l}\text { Federal and state governments pay about } 1500 \\
\text { pesos to each producer per hectare affected by } \\
\text { climatic events; provided at no cost to subsistence } \\
\text { farmers and paid if there is a loss of } 30 \% \text { of the } \\
\text { insured area }\end{array}$ & SAGARPA \\
\hline Climate forecasts & $\begin{array}{l}\text { Trimestral meeting to present weather forecasts } \\
\text { for the next four months. With this information, } \\
\text { representatives of the secretariats of rural } \\
\text { development promote incentives or propose } \\
\text { agricultural activities. }\end{array}$ & $\begin{array}{l}\text { INIFAP and the Secretaries of } \\
\text { Rural Development of each state }\end{array}$ \\
\hline Maize Product System & $\begin{array}{l}\text { In Campeche and Quintana Roo, committee } \\
\text { created under the Law of Sustainable Rural } \\
\text { Development, to establish the rules for maize } \\
\text { production process; includes subsidies for } \\
\text { technical equipment, supplies and services for } \\
\text { production, gathering, processing, distribution, } \\
\text { and marketing. }\end{array}$ & $\begin{array}{l}\text { National Product System } \\
\text { Committee }\end{array}$ \\
\hline
\end{tabular}

In addition, a variety of funding possibilities, for financing agricultural infrastructure and inputs, are offered by several governmental agencies such as the Ministry of Economy (SE), Rural Finance (FR), Trusts Established in Relation to Agriculture (FIRA), and the National Fund for Support to Companies in Solidarity (FONAES). Source: Government institutions' websites and interviews.

1 Amounts to between 2200 and 2400 pesos per hectare annually, not exceeding 6600 pesos per producer.

2 Between 7000 and 10,000 pesos in the Peninsula, compared to 40,000 pesos in Sinaloa. 


\section{Appendix B}

Table A2. Summary of drivers for maize production trends in Mexico's Yucatan Peninsula.

\begin{tabular}{|c|c|c|c|}
\hline & Campeche & Quintana Roo & Yucatan \\
\hline \multicolumn{4}{|l|}{ Soils } \\
\hline $\begin{array}{l}\text { Leptosol soils as percent of all soils } \\
\text { (limit agricultural potential by their } \\
\text { shallow depth and high stoniness) }\end{array}$ & $29 \%$ & $30 \%$ & $56 \%$ \\
\hline $\begin{array}{l}\text { Percent of lands classified by National } \\
\text { Institute of Statistics, Geography, and } \\
\text { Informatics (INEGI) as not suitable for } \\
\text { agriculture (from all lands) }\end{array}$ & $2 \%$ & $2 \%$ & $20 \%$ \\
\hline $\begin{array}{l}\text { Percent of mechanized agricultural soils } \\
\text { (2015) }\end{array}$ & $60 \%$ & $37 \%$ & $3 \%$ \\
\hline \multicolumn{4}{|l|}{ Climate trends, $1981-2010$} \\
\hline Monthly maximum temperature & Negative trend & Positive trend & Positive trend \\
\hline Monthly minimum temperature & Positive trend & Positive trend & Positive trend \\
\hline Total precipitation & No change & Negative trend & No change \\
\hline $\begin{array}{l}\text { Percent of correlation between maize } \\
\text { production and climate variability }\end{array}$ & $79 \%$ & $72 \%$ & $31 \%$ \\
\hline \multicolumn{4}{|l|}{ Agricultural policy } \\
\hline $\begin{array}{l}\text { SAGARPA's budget, 2007-2010 } \\
\text { (Mexican pesos) }\end{array}$ & $\$ 2,523,454,658$ & $\$ 1,223,942,219$ & $\$ 1,966,909,819$ \\
\hline $\begin{array}{l}\text { Money provided by PROCAMPO, } \\
\text { 2006-2012 (Mexican pesos) }\end{array}$ & $\$ 1,150,989,062$ & $\$ 685,460,264$ & $\$ 938,348,210$ \\
\hline $\begin{array}{l}\text { Percent of Federal Expending (PEF) } \\
\text { devoted to agricultural sector }\end{array}$ & $10 \%$ & $7.6 \%$ & $7.2 \%$ \\
\hline $\begin{array}{l}\text { Percent of maize surface planted with } \\
\text { improved (hybrid) seeds }\end{array}$ & $56 \%$ & $28 \%$ & $22 \%$ \\
\hline $\begin{array}{l}\text { Percent of maize surface planted under } \\
\text { technical assistance }\end{array}$ & $5.5 \%$ & $6.5 \%$ & $14 \%$ \\
\hline
\end{tabular}

\section{References}

1. Parry, M.L.; Carter, T.R. An assessment of the effects of climatic change on agriculture. Clim. Chang. 1989, 15, 95-116. [CrossRef]

2. Reilly, J.M.; Baethgen, W.; Chege, F.; Van de Geijn, F.E.; Lin, S.C.; Iglesias, E.; Kenny, A.; Patterson, D.; Rogasik, J.; Roetter, R.; et al. Agriculture in a changing climate: Impacts and adaptation. In Climate Change 1995: Intergovernmental Panel on Climate Change Impacts, Adaptations and Mitigation of Climate Change. Scientific-Technical Analyses; Watson, R.T., Zinyowera, M.C., Moss, H.R., Eds.; Cambridge University Press: Cambridge, UK, 1996; pp. 427-467.

3. Smith, P.M.; Bustamante, H.; Ahammad, H.; Clark, H.; Dong, E.A.; Elsiddig, H.; Haberl, R.; Harper, J.; House, M.; Jafari, O.; et al. Agriculture, Forestry and Other Land Use (AFOLU). In Climate Change 2014: Mitigation of Climate Change. Contribution of Working Group III to the Fifth Assessment Report of the Intergovernmental Panel on Climate Change; Edenhofer, O.R., Pichs-Madruga, Y., Sokona, E., Farahani, S., Kadner, K., Seyboth, A., Adler, I., Baum, S., Brunner, P., Eickemeier, B., et al., Eds.; Cambridge University Press: Cambridge, UK; New York, NY, USA, 2014.

4. Smit, B.; Burton, I.; Klein, R.J.; Wandel, J. An anatomy of adaptation to climate change and variability. Clim. Chang. 2000, 45, 223-251. [CrossRef]

5. Bryant, C.R.; Smit, B.; Brklacich, M.; Johnston, T.R.; Smithers, J.; Chjotti, Q.; Singh, B. Adaptation in Canadian agriculture to climatic variability and Change. Clim. Chang. 2000, 45, 181-201. [CrossRef] 
6. Vadjunec, J.M.; Radel, C.; Turner, B.L., II. Introduction: The continued importance of smallholders today. Land 2016, 5, 34. [CrossRef]

7. Eakin, H. Institutional change, climate risk, and rural vulnerability: Cases from Central Mexico. World Dev. 2005, 33, 1923-1938. [CrossRef]

8. Leichenko, R.M.; O'Brien, K.L. The dynamics of rural vulnerability to global change: The case of Southern Africa. Mitig. Adapt. Strateg. Glob. Chang. 2002, 7, 1-18. [CrossRef]

9. Scoones, I.; Chibudu, C.; Chikura, S.; Jeranyama, P.; Machaka, D.; Machanja, W.; Mavedzenge, B.; Mombeshra, B.; Mudhara, M.; Mudziwo, C.; et al. Hazards and Opportunities: Farming Livelihoods in Dryland Africa. Lessons from Zimbabwe; Zed Books: London, UK, 1996; 283p, ISBN 1-85649-354-7.

10. Silva, J.A.; Eriksen, S.; Ombe, Z.A. Double exposure in Mozambique's Limpopo River basin. Geogr. J. 2010, 176, 6-24. [CrossRef]

11. Mardero, S.; Nickl, E.; Schmook, B.; Schneider, L.; Rogan, J.; Christman, Z.; Lawrence, D. Sequías en el sur de la península de Yucatan: Análisis de la variabilidad anual y estacional de la precipitación. Investig. Geogr. 2012, 19-33. Available online: http:/ / www.scielo.org.mx/scielo.php?script=sci_arttext\&pid=S018846112012000200003 (accessed on 7 December 2016). [CrossRef]

12. Hernández Cerda, M.E.; Torres Tapia, L.A.; Valdez Madero, G. Sequía meteorológica. In México: Una Visión Hacia el Siglo XXI; Gay García, C., Ed.; Instituto Nacional de Ecología, Universidad Nacional Autónoma de México: Mexico City, Mexico, 2000; 220p.

13. Orellana, R.; Espadas, C.; Conde, C.; Gay, C. Atlas: Escenarios de Cambio Climático en la Península de Yucatan; Centro de Investigación Científica de Yucatan, A.C.: Yucatan, Mexico, 2009; ISBN 978-607-7823-01-8.

14. Alcantara, E.A. Soil Fertility in Calcareous Tropical Soils from Yucatan, Mexico and Villa Clara, Cuba, Affected by Land Use and Soil Moisture Effects; Cuvillier Verlag: Göttingen, Germany, 2007; 147p.

15. Sutton, W.R.; Block, R.I.; Srivastana, J. Adaptation to Climate Change in Europe and Central Asia Agriculture; World Bank: Washington, DC, USA, 2009.

16. Schmook, B.; Van Vliet, N.; Radel, C.; Manzón-Che, M.J.; McCandless, S. Persistence of Swidden cultivation in the face of globalization: A case study from communities in Calakmul, Mexico. Hum. Ecol. 2013, 41, 93-107. [CrossRef]

17. Babel, M.S.; Agarwal, A.; Swain, D.K.; Herath, S. Evaluation of climate change impacts and adaptation measures for rice cultivation in Northeast Thailand. Clim. Res. 2011, 46, 137-146. [CrossRef]

18. Berg, A.; De Noblet-Ducoudré, N.; Sultan, B.; Lengaigne, M.; Guimberteau, M. Projections of climate change impacts on potential C4 crop productivity over tropical regions. Agric. For. Meteorol. 2013, 170, 89-102. [CrossRef]

19. Bhatt, D.; Maskey, S.; Babel, M.S.; Uhlenbrook, S.; Prasad, K.C. Climate trends and impacts on crop production in the Koshi River basin of Nepal. Reg. Environ. Chang. 2014, 14, 1291-1301. [CrossRef]

20. Luo, Q.; Bellotti, W.; Williams, M.; Wang, E. Adaptation to climate change of wheat growing in South Australia: Analysis of management and breeding strategies. Agric. Ecosyst. Environ. 2009, 129, 261-267. [CrossRef]

21. Parry, M.L.; Rosenzweig, C.; Iglesias, A.; Livermore, M.; Fischer, G. Effects of climate change on global food production under SRES emissions and socio-economic scenarios. Glob. Environ. Chang. 2004, 14, 53-67. [CrossRef]

22. O'Brien, K.L.; Leichenko, R.M. Double exposure: Assessing the impacts of climate change within the context of economic globalization. Glob. Environ. Chang. 2000, 10, 221-232. [CrossRef]

23. Warman, A. El Campo Mexicano en el Siglo XX; Fondo de Cultura Económica, Ciudad de México: Mexico City, Mexico, 2002; ISBN 0-12-710003-2.

24. "Panorama Agroalimentario Maíz 2016". Dirección de Investigación y Evaluación Económica y Sectorial, FIRA. Available online: https:/ /www.gob.mx/cms/uploads/attachment/ file/200637/Panorama_ Agroalimentario_Ma_z_2016.pdf (accessed on 25 January 2017).

25. SIAP Informa. Available online: http://www.campomexicano.gob.mx/boletinsiap/014-e.html (accessed on 25 January 2017).

26. Appendini, K. Reconstructing the maize market in rural Mexico. J. Agrar. Chang. 2014, 14, 1-25. [CrossRef]

27. Robles, H.M.; Ruíz, A.J. Presupuesto Para la Agricultura Familiar y Campesina de México; OXFAM México: Mexico City, Mexico, 2012. 
28. SIAP (Agricultural and Fisheries Information Service) Statistical Yearbook of Agricultural Production, Government of Mexico. 2015. Available online: https:/ / www.gob.mx/siap (accessed on 25 January 2017).

29. Galindo, L.M. La Economía del Cambio Climático en México: Síntesis; SEMARNAT: Mexico City, Mexico, 2009.

30. Gay, C.; Estrada, F.; Conde, C.; Eakin, H. Impactos Potenciales del Cambio Climático en la Agricultura: Escenarios de Producción de Café Para el 2050 en Veracruz (México); El Clima, entre el Mar y la Montaña, University of Cantabria: Santander, Spain, 2004; pp. 651-660.

31. Méndez-González, J.; Návar-Cháidez, J.D.; González-Ontiveros, V. Análisis de tendencias de precipitación (1920-2004) en México. Investig. Geogr. 2008, 38-55. Available online: http://www.scielo.org.mx/scielo.php? pid=S0188-46112008000100004\&script=sci_arttext (accessed on 3 March 2017).

32. Appendini, K.; Liverman, D. Agricultural policy, climate change and food security in Mexico. Food Policy 1994, 19, 149-164. [CrossRef]

33. Rogan, J.; Schneider, L.; Christman, Z.; Millones, M.; Lawrence, D.; Schmook, B. Hurricane disturbance mapping using MODIS EVI data in the southeastern Yucatán, Mexico. Remote Sens. Lett. 2011, 2, $259-267$. [CrossRef]

34. Conde, C.; Ferrer, R.; Orozco, S. Climate change and climate variability impacts on rainfed agricultural activities and possible adaptation measures. A Mexican case study. Atmósfera 2006, 19, 181-194.

35. Instituto Nacional de Ecología y Cambio Climático INECC. Available online: http:/ / www.escenarios.inecc. gob.mx/ (accessed on 25 February 2017).

36. Eakin, H.; Lerner, A.M.; Murtinho, F. Adaptive capacity in evolving peri-urban spaces: Responses to flood risk in the Upper Lerma River Valley, Mexico. Glob. Environ. Chang. 2010, 20, 14-22. [CrossRef]

37. Burstein, J. Comercio Agrícola México-Estados Unidos y la Pobreza Rural en México; Woodrow Wilson Center for Scholars: Washington, DC, USA, 2007; 17p.

38. Fox, J.; Haight, L. Subsidizing Inequality: Mexican Corn Policy Since NAFTA; Woodrow Wilson International, University of California: Santa Cruz, CA, USA, 2010.

39. Sweeney, S.; Steigerwald, D.G.; Davenport, F.; Eakin, H. Mexican maize production: Evolving organizational and spatial structures since 1980. Appl. Geogr. 2013, 39, 78-92. [CrossRef]

40. Yúnez-Naude, A. Liberalización y reformas al agro: Lecciones de México. Econ. Agrar. Recur. Nat. 2006, 6, 47-68. [CrossRef]

41. Yúnez-Naude, A. The Dismantling of CONASUPO, a Mexican State Trader in Agriculture. World Econ. 2003, 26, 97-122. [CrossRef]

42. Cornelius, W.A.; Myhre, D. The Transformation of Rural Mexico: Reforming the Ejido Sector; Center for US Mexican Studies, University of California: San Diego, CA, USA, 1998.

43. De Ita Rubio, A. Los Impactos Socioeconómicos y Ambientales de la Liberalización Comercial de Los Granos Básicos en el Contexto del TLCAN: El Caso de Sinaloa; Centro Mexicano de Derecho Ambiental, Ciudad de México: Mexico City, Mexico, 2003.

44. Eakin, H.; Perales, H.; Appendini, K.; Sweeney, S. Selling maize in Mexico: The persistence of peasant farming in an era of global markets. Dev. Chang. 2014, 45, 133-155. [CrossRef]

45. Gómez-Cruz, M.A.; Rindermann, S.R. El sistema hortofrutícola en México frente al TLC. In Alternativas Para el Campo Mexicano; Calva, J.L., Ed.; Fontamara-UNAM-PUAL, Ciudad de México: Mexico City, Mexico, 1993; $135 \mathrm{p}$.

46. FUNDAR Centro de Análisis e Investigación. 2010. Available online: http://subsidiosalcampo.org.mx/ (accessed on 7 March 2017).

47. González-Estrada, A.; Orrantia-Bustos, M.A. Los subsidios agrícolas de México. Agric. Téc. Méx. 2006, 32, 323-331.

48. Raisz, E. Landforms of México; Prepared for the Geography Branch of the Office of Naval Research; Institute of Geographical Exploration, Harvard University: Cambridge, MA, USA, 1964.

49. Bautista, F. El Suelo. In Biodiversidad y Desarrollo Urbano en Yucatán; SEDUMA: Mérida, Mexico, 2010.

50. Bautista, F.; Frausto, O.; Ihl, T.; Aguilar, Y. Actualización del mapa de suelos del Estado de Yucatán México: Enfoque geomorfopedológico y WRB. Ecosist. Recur. Agropecu. 2015, 2, 303-315.

51. Duch, G.J. La Conformación Territorial del Estado de Yucatan-Los Componentes del Medio Físico; Centro Regional de la Península de Yucatan (CRUPY), Universidad Autónoma de Chapingo: México City, México, 1988.

52. Cowgill, U.M. An agricultural study of the southern Maya lowlands. Am. Anthropol. 1962, 64, $273-286$. [CrossRef] 
53. Magier, J.; Rabina, I. Rock fragments and soil depth as factors in land evaluation of terra rossa. Spec. Publ. Soil Sci. Soc. Am. 1984, 1, 13-30.

54. Instituto Nacional de Investigaciones Forestales Agrícolas y Pecuarias. Available online: http://www.inifap. gob.mx/SitePages/Inicio.aspx (accessed on 13 December 2016).

55. INEGI (National Institute of Statistics, Geography and Informatics). Statistical and Geographical Yearbooks of the National Institute of Statistics, Geography and Informatics; INEGI: Aguascalientes, Mexico, 2017.

56. Lugo-Hubp, J.; Aceves-Quesada, J.F.; Espinaza-Pereño, R. Rasgos geomorfológicos mayores de la península de Yucatan. Rev. Mex. Cienc. Geol. 1992, 10, 143-150.

57. Vidal-Zepeda, R. Las Regiones Climáticas de México; Instituto de Geografía, UNAM: Mexico City, México, 2005; pp. 137-138.

58. Reyes-Hernández, H.; Cortina-Villa, S.; Perales-Rivera, H.; Kauffer-Michel, E.; Pat-Fernández, J.M. Efecto de los subsidios agropecuarios y apoyos gubernamentales sobre la deforestación durante el período 1990-2000 en la región de Calakmul, Campeche, México. Investig. Geogr. 2003, 88-106. Available online: http:/ /www. scielo.org.mx/scielo.php?pid=S0188-46112003000200007\&script=sci_arttext (accessed on 3 March 2017).

59. Johnson, R.B.; Onwuegbuzie, A.J.; Turner, L.A. Toward a definition of mixed methods research. J. Mixed Methods Res. 2007, 1, 112-133. [CrossRef]

60. Johnson, R.B.; Anthony, J.O. Mixed methods research: A research paradigm whose time has come. Educ. Res. 2004, 33, 14-26. [CrossRef]

61. Berg, B.L. Qualitative Research Methods for the Social Sciences; Pearson Education: Boston, MA, USA, 2004.

62. Creswell, J.W.; Plano-Clark, V.L. Designing and Conducting Mixed Methods Research, 2nd ed.; SAGE Publications, Inc.: Thousand Oaks, CA, USA, 2007.

63. Jones, A.; Bugge, C. Improving understanding and rigour through triangulation: An exemplar based on patient participation in interaction. J. Adv. Nurs. 2006, 55, 612-621. [CrossRef] [PubMed]

64. Zuur, A.F.; Ieno, E.N.; Walker, N.J.; Saveliev, A.A.; Smith, G.M. Mixed Effects Models and Extensions in Ecology with R; Spring Science and Business Media: New York, NY, USA, 2009.

65. Hastie, T.; Tibshirani, R. Generalized additive models. Stat. Sci. 1986, 1, 297-318. [CrossRef]

66. Dominici, F.; McDermott, A.; Zeger, S.L.; Samet, J.M. On the use of generalized additive models in time-series studies of air pollution and health. Am. J. Epidemiol. 2002, 156, 193-203. [CrossRef] [PubMed]

67. R Core Team. R: A Language and Environment for Statistical Computing; R Core Team: Vienna, Austria, 2016.

68. Wood, S.N. Fast stable restricted maximum likelihood and marginal likelihood estimation of semiparametric generalized linear models. J. R. Stat. Soc. 2001, 73, 3-36. [CrossRef]

69. Glaser, B.G.; Strauss, A. The Discovery of Grounded Theory; Aldine Transaction: Chicago, IL, USA, 1967.

70. Flick, U. Introducción a la Investigación Cualitativa; Morata: Madrid, Spain, 2004.

71. Hernández-Carrera, R.M. La investigación cualitativa a través de entrevistas: Su Análisis Mediante la Teoría Fundamentada. Cuest. Pedagóg. 2014, 23, 187-210.

72. Friese, S. Qualitative Data Analysis with ATLAS.ti; SAGE: London, UK, 2009.

73. Adger, W.N. Social vulnerability to climate change and extremes in coastal Vietnam. World Dev. 1999, 27, 249-269. [CrossRef]

74. Klepeis, P. Development policies and tropical deforestation in the southern Yucatán peninsula: centralized and decentralized approaches. Land Degrad. Dev. 2003, 14, 541-561. [CrossRef]

75. Hibon, A.; Triomphe, B.; Pereira, L.; Saad Alvarado, L. Rainfed Maize Production in Mexico: Trends, Constraints, and Technological and Institutional Challenges for Researchers; CIMMYT Economics Working Paper; CIMMYT: México City, México, 1992.

76. Mardero, S.; Schmook, B.; Radel, C.; Christman, Z.; Lawrence, D.; Millones, M.; Nickl, E.; Rogan, J.; Schneider, L. Smallholders' adaptations to droughts and climatic variability in southeastern Mexico. Environ. Hazards 2015, 14, 271-288. [CrossRef]

77. Appendini, K. From Crisis to Restructuring: The Debate on the Mexican Economy during the 1980s; Center for Development Research: Copenhague, Denmark, 1992.

78. Echánove, F.; Steffen, C. Agribusiness and farmers in Mexico: The importance of contractual relations. Geogr. J. 2005, 171, 166-176. [CrossRef]

79. Drought Facts, FAO Land \& Water. 2013. Available online: http://www.fao.org/docrep/017/aq191e/ aq191e.pdf (accessed on 9 March 2017). 
80. Fourth Assessment Report IPCC. 2007. Available online: https://www.ipcc.ch/pdf/assessment-report/ar4/ wg2/ar4_wg2_full_report.pdf (accessed on 9 March 2017).

81. Gourdji, S.; Läderach, P.; Martinez Valle, A.; Zelaya Martinez, C.; Lobell, D.B. Historical climate trends, deforestation, and maize and bean yields in Nicaragua. Agric. For. Meteorol. 2015, 200, 270-281. [CrossRef]

82. Thornton, P.K.; Jones, P.G.; Ericksen, P.J.; Challinor, A.J. Agriculture and food systems in sub-SaharanAfrica in a $4{ }^{\circ} \mathrm{C}+$ world. Philos. Trans. R. Soc. Lond. A Math. Phys. Eng. Sci. 2011, 369, 117-136. [CrossRef] [PubMed]

83. Chiotti, Q.; Johnston, T.; Smit, B.; Ebel, B. Agricultural response to climate change: A preliminary investigation of farm-level adaptation in Southern Alberta. In Agricultural Restructuring and Sustainability: A Geographical Perspective; Libery, B., Chiotti, Q., Richard, T., Eds.; CAB International: Wallingford, UK, 1997; pp. 167-183.

84. Freebairn, D.K. Did the Green Revolution concentrate incomes? A quantitative study of research reports. World Dev. 1995, 23, 265-279. [CrossRef]

85. Valor al Campesino. Available online: http://valoralcampesino.org/ (accessed on 21 May 2017).

86. Bartra, A. A Persistent Rural Leviathan. In Reforming Mexico's Agrarian Reform; Randall, L., Ed.; M.E. Sharpe. Columbia University: New York, NY, USA, 1996; pp. 173-184.

87. Eakin, H.; Lemos, M.C. Adaptation and the state: Latin America and the challenge of capacity-building under globalization. Glob. Environ. Chang. 2006, 16, 7-18. [CrossRef]

88. Radel, C.; Schmook, B.; Haenn, N.; Green, L. The gender dynamics of conditional cash transfers and smallholder farming in Calakmul, Mexico. Womens Stud. Int. Forum 2017, 65, 17-27. [CrossRef]

89. Olvera, B.; Schmook, B.; Radel, C.; Nazar, A. Efectos adversos de los programas de apoyo alimenticio en los hogares rurales de Calakmul, Campeche. Rev. Aliment. Contemp. Desarro. Reg. 2017, 27, 11-46.

90. Arce, M.; Carrillo, L.; Infante, K. Inclusión de los Sistemas Productivos Rurales de Pequeña Escala en la Agenda Pública de Mitigación y Vulnerabilidad al Cambio Climático; Recomendaciones de Política, El Colegio de la Frontera Sur: México City, México, 2018.

91. Vergara, W.; Rios, A.R.; Trapido, P.; Malarín, H.R. Agricultura y Clima Futuro en América Latina y el Caribe: Impactos Sistémicos y Posibles Respuestas; Banco Interamericano de Desarrollo, No. IDB-DP-329; Banco Interamericano de Desarrollo: Washington, DC, USA, 2014; pp. 1-9.

(C) 2018 by the authors. Licensee MDPI, Basel, Switzerland. This article is an open access article distributed under the terms and conditions of the Creative Commons Attribution (CC BY) license (http://creativecommons.org/licenses/by/4.0/). 